\title{
The Effect of Service Orientation, Perceived Organizational Support, Job Satisfaction, Towards Employee Engagement in Cikini Hotel, Jakarta
}

\author{
Rahma Dimitri Arifin, Dita Oki Berliyanti, Beta Oki Baliartati* \\ Faculty of Economics and Business \\ Universitas Trisakti \\ Jakarta, Indonesia \\ *betaokibarliartati.2014@gmail.com
}

\begin{abstract}
This research aims to analyze the impact of employee engagement, service orientation, perceived organizational support, and job satisfaction at Cikini hotel in jakarta. Data were obtained directly by distributing questionnaires to 130 respondents and analyzed using the simple regression analysis and SPSS. The result showed that employee engagement has a positive impact on service orientation, perceived organizational support, and job satisfaction. In addition, the results can be used as theoretical implications for further studies.
\end{abstract}

Keywords-employee engagement, service orientation, perceived organizational support, job satisfaction

\section{INTRODUCTION}

\section{A. Background}

Hospitality is one of the supporting factors of the tourism industry, due to the increasing needs of tourists to acquire a comfortable and cozy place to rest. Presently, the existence of this industry keeps progressing by offering a variety of facilities that affords tourists and business persons the opportunity to choose their hotel. According to data from the Inbound Outbound survey, the number of tourists that visited Jakarta over the past three years keeps increasing. For example, in 2014, over 2,319,295 visits were recorded, and this increased to $2,512,005$ in 2016 [1].

Furthermore, data obtained from BPS DKI Jakarta stated that in 2016 [1], the average Room Occupancy Rate (TPK) for hotels in Indonesia was approximately 62.28 percent. The TPK for the star and non-star hotels was estimated to be $61.17 \%$ and $68.60 \%$, respectively. The lowest for star hotels was $54.24 \%$ in January, while the highest was estimated at $67.29 \%$ in October. However, the non-star hotels had the lowest TPK at $60.47 \%$ in April, and the highest at 79.90\% occurred in October 2016.

According to a 2016 data on hotel classifications, the highest and lowest average room occupancy, occurred in two and five -star hotels, with percentages of $68.16 \%$ and $49.57 \%$, respectively. However, in accordance with the results from the data, it is evident that the highest room occupancy rate is the two-star hotels, while the least is the five-star hotels [1]. Twostar hotels are usually located in easily accessible locations, particularly in the middle of the city. The existing facilities are en suite bathrooms, telephones, televisions, doors equipped with safety devices, air conditioners, toiletries such as towels, and toothpaste. These hotels have a minimum of 20 rooms, 1 suite, and a lobby for receiving guests. In addition, some of the hotels consist of sports/recreational facilities, a restaurant for breakfast, and a bar [2]. It also acts as budget hotels, due to its location at the center of the city, the availability of comfortable facilities.

The data obtained from the three budget hotels in Cikini was analyzed and shown on a table on traveloka.com. The table showed that the Cikini hotel had the highest ratings (8.5) from 3,823 visitors, followed by the Ibis Budget Hotel with a rating of 8.3 from 3,741 visitors, and the Whiz Hotel with a rating of 8.2 from 6,589 guests. In accordance with table 1 , the highest rating is the Cikini Hotel, located in Menteng. It is famous for its office centers, tourist destinations, various culinary delights, and several accommodations for tourists or business persons. This is evidence of adequate employee engagement.

According to Singh et al [3], employee engagement is important in any company because its presence has a huge influence on the progress and development of productivity. It also has an impact on service orientation because it causes employees to put in their best and boosts the worker's service orientation to a better level [4].

Additionally, a good service orientation tends to satisfy the needs and desires of a customer, and this helps to create an excellent customer-client relationship with loyalty to the company [5]. In the current business conditions, it is the main concept for companies engaged in services because every company needs a good assessment from customers [5]. Furthermore, perceived organizational support in a company tends to increase the productive contribution of employees through reciprocity by evaluating and creating more workers 
[6]. However, in this research, the relationship between perceived organizational support and employee participation was rarely studied. In a company where organizational support is highly felt, employees find the work environment more acceptable, and they tend to get more involved in their work [7].

\section{LITERATURE REVIEW}

\section{A. Service Orientation}

According to Lytle and Timmerman [8], the practice of service orientation is the company's interaction with each customer. However, Bowen and Schneider [9], stated that an employee's willingness to treat coworkers and customers politely, involves an understanding of the clients' needs and the ability to communicate accurately, effectively and pleasantly.

\section{B. Perceived Organizational Support}

This is defined as the perception of employees when they feel valued by a company. Therefore, companies tend to provide support and aids its workers in carrying out their duties with the expectation that they help in achieving its get objectives [10]. According to Mishra [11], perceived organizational support is an employees' view of the company in accordance with the extent to which it offers support and welfare to staffs. It is also defined as the belief of employees regarding the company's value of hard work and concern for the welfare of its staff [12]. Therefore, the most experts believe the POS company supports all the activities of its employees, cares and appreciates their hard work [10-12].

\section{Job Satisfaction}

Job satisfaction is the affective orientation of employees towards their work as well as the perceptions of various features, especially aspects of work. It is a position where a person has positive thoughts concerning the job. Subsequently, Chang and Lee reported that job satisfaction is the mental and physical satisfaction of the employees' environment, and its level is ascertained by inquiring about it from the workers [13].

\section{Employee Engagement}

Employee engagement is a major issue in an increasingly fierce competitive business environment. It is a positive attitude that is physically, cognitively, and emotionally bound towards the work and the organization, which leads to loyalty. Employee engagement is also defined as the attitude of workers that are completely involved in their work with a high sense of enthusiasm. However, with this behavior, they tend to act in ways that advance the interests of the organization [14].

Employee engagement is important in a company because it has a huge influence on the progress and development of productivity [3]. In the service industry, it tends to affect service orientation due to the fact that employee engagement encourages workers to put in their best at work to strengthen a staff's service orientation to a better level [4]. Perceived organizational support increases the productive contribution of employees through evaluative reciprocal assistance and creates more employee engagement [6].

In accordance with the description, the conceptual framework is formed as follows figure 1 .

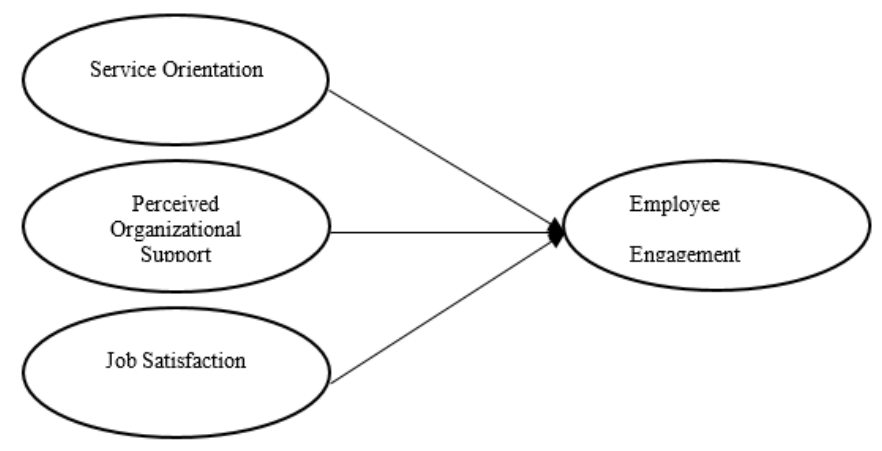

Fig. 1. Conceptual framework.

\section{E. Hypothesis Development}

Employee engagement tends to affect service orientation because it motivates workers to put in their best, thereby, boosting employees' service orientation to a better level [4]. The data used for the above survey was obtained from 329 respondents, and it was carried out in several service sectors in the NCR region, India. Furthermore, employee engagement is an important element in improving service orientation because by involving the staff, they tend to feel valued and have enthusiasm in carrying out their work [15]. The survey associated with this statement obtained data from 240 respondents in various service industries in Istanbul, Turkey. According to previous studies, service orientation has an effect on employee engagement [16], and the survey acquired data from 231 respondents, and it was conducted in several hotels in Jamaica. Based on the results from previous research concerning service orientation on employee engagement, the following hypothesis is deduced as follows:

H1. Service Orientation has a positive effect on Employee Engagement

Perceived organizational support increases the productive contribution of employees through evaluative reciprocal assistance, and these results in an increase in employee engagement [6]. The survey conducted acquired data from 325 respondents of the department of industrial organizations in Iran. Saks and Rotman stated that employees that experience a higher level of organizational support are more likely to put in their best in the organization [17]. This survey obtained data from 102 respondents from several organizations in Toronto, Canada. The results show that organizational support positively influences employee engagement [18]. This survey was carried out with data from 410 respondents of various public and private educational institutions in Delhi, India. 
In accordance with the results from previous research concerning perceived organizational support on employee engagement, the hypothesis is stated as follows:

H2. Perceived Organizational Support has a positive effect on Employee Engagement

Employees that exhibited strong and positive attachment towards their organizations tend to be more involved, passionate, and dedicated to their work, and also have job satisfaction [19]. This survey acquired data from 194 employees from three organizations in the UK. Therefore, job satisfaction has a significant effect on employee engagement [20]. This survey obtained data from 197 respondents and was conducted at a BPO company in Delhi / NCR.

According to the results from previous research regarding job satisfaction on employee engagement, the hypothesis is stated as follows

\section{H3. Job Satisfaction has a positive effect on Employee} Engagement.

\section{RESEARCH METHOD}

The research used the hypothesis testing method, to obtain data from employees. Data collection was carried out through a cross-sectional method because it was acquired during a specific period. This study was conducted by distributing questionnaires.

The sample in this research was the Cikini Hotel, while non-probability was used for sampling. The sampling method employed a purposive sampling technique. The number of samples was 40 respondents with the following characteristics age, work units, education level, and marital status.

\section{A. Data Analysis Method}

In this study, the analytical tool used to evaluate each variable was the multiple regression analysis using the SPSS program. The data analysis methods used in this research aim to achieve the following: (1) study the service orientation of employees in Cikini Hotel by using descriptive statistics and studying the mean values of the respondents' answers to the item statements given, (2) examine perceived organizational support of the workers by using descriptive statistics and evaluating the mean values of respondents' answers to the item statement provided, (3) examine the job satisfaction using descriptive statistics by observing the mean values of the respondents 'answers to item statements realized, (4) determine the employee engagement by employing descriptive statistics and considering the mean values of respondents' answers to the given item statements and (5) analyze the effect of service orientation, perceived organizational support, job satisfaction and employee engagement using multiple regression analysis with SPSS software version 24.0.

\section{RESULTS AND DISCUSSION}

\section{A. Results}

According to the results from the descriptive statistical analysis, the service orientation variable had an average value of 4.030. It shows that the employees of the Cikini hotel agreed that the service orientation enforced in the company was in accordance with their expectations and was properly implemented.

TABLE I. The RESUlTS OF HyPOTHESIS TESTING

\begin{tabular}{|l|l|l|l|}
\hline \multicolumn{1}{|c|}{ Hypothesis } & $\begin{array}{l}\text { Coefficient } \\
\text { Regression }\end{array}$ & p-value & Decision \\
\hline $\begin{array}{l}\text { H1: service orientation } \\
\text { has a positive effect on } \\
\text { Employee Engagement }\end{array}$ & 0.353 & 0.018 & $\begin{array}{l}\mathrm{H} \text { was } \\
\text { accepted }\end{array}$ \\
\hline $\begin{array}{l}\text { H2: perceived } \\
\text { organizational support has a } \\
\text { positive effect on Employee } \\
\text { Engagement job satisfaction has }\end{array}$ & 0.295 & 0.025 & $\begin{array}{l}\mathrm{H} 2 \quad \text { was } \\
\text { accepted }\end{array}$ \\
\hline $\begin{array}{l}\text { H3: } \\
\text { a positive effect on Employee } \\
\text { Engagement }\end{array}$ & 0.529 & 0.000 & $\begin{array}{l}\mathrm{H} 3 \\
\text { accepted was }\end{array}$ \\
\hline
\end{tabular}

\section{B. Discussion}

In accordance with the results from hypothesis testing, the significant value ( $p$-value) for testing the positive effect of service orientation on employee engagement obtained a $p$-value of $0.018<0.05$ with a regression coefficient $(\beta)$ of 0.353 . Therefore, it was concluded that service orientation has a positive effect on employee engagement. This shows that increased employee engagement further improves the service orientation of the workers. It was, however concluded that workers that exhibited high levels of employee engagement and demonstrated better service orientation within the company.

Based on the results from hypothesis testing, the significant value (p-value) for testing the positive effect of perceived organizational support on employee engagement obtained a $\mathrm{p}$ value of $0.025<0.05$ with a regression coefficient $(\beta)$ of 0.295 . Therefore, it was concluded that perceived organizational support has a positive effect on employee engagement. This shows that the higher the level of perceived organizational support, the higher the level of employee engagement. It was therefore concluded that employees that enjoyed perceived organizational support from the company strive to increase employee engagement to a higher level because it causes workers to try to put in their best in work.

In accordance with the results from hypothesis testing, the significant value (p-value) for testing the positive effect of job satisfaction on employee engagement obtained a $p$-value of $0,000>0.05$ with a regression coefficient $(\beta)$ of 0.529 . Therefore, it was concluded that job satisfaction has a positive 
effect on employee engagement. This shows that increased job satisfaction tends to heighten employee engagement. It was concluded that job satisfaction increases employee engagement, therefore the workers are satisfied with their work and seriously complete all assigned duties and responsibilities.

\section{CONCLUSIONS}

Based on the results and discussion, the following conclusions were obtained: 1) All the employees of the Cikini Hotel agreed that the implementation of service orientation in the company was in accordance with the expectations, 2) All employees at the hotel have a good perceived organizational support. This shows that they agreed that maximum organizational support had been provided to them, with the provision of bonuses to the best staff through awards at the end of each year, 3) The results from the analysis of job satisfaction variable stated that the employees are satisfied with their jobs. This shows that they enjoy working in the company. This is also observed from the profile of respondents at the level of work tenure. At the level of work tenure, it is observed that the largest respondents are employees who work $>1$ year with a total of 20 workers or 50.0. This means that they appreciate new experiences and have the desire to explore their work further., and 4) The results from the analysis of employee engagement variable stated that the employees have a strong sense of attachment to their work. This shows that they agreed that the energy used needs to be maximum, in other to carry out their work with enthusiasm

This research provides several managerial implications that tend to be used as suggestions for managers, especially in corporate decision making, 1) The service orientation has been properly analyzed, managers are expected to maintain and motivate their employees through communication in order to build and improve their work abilities, 2) The perceived organizational support has also been effectively examined, managers are expected to maintain the management and development of human resources by improving the welfare of the employees, 3) The job satisfaction has been carefully evaluated; managers are anticipated to make payment of salaries in accordance with the performance of each employee that has reached it targets. This causes the workers to feel satisfied with their work, and 4) The employee engagement has been thoroughly investigated, the executives are anticipated to be able to maintain the organization through training, development, and interaction with employees in order that they are more exposed to develop their skills.

In this research, there are several limitations, such as 1) It was only conducted in one company, Cikini Hotel Jakarta, 2) It examined only the employees at the hotel as respondents, and 3 ) It used only 4 variables, which are service orientation, perceived organizational support, job satisfaction, and employee engagement

Suggestions are provided for further research in order to improve the limitations that exist in this study. They are as follows: Further researches are expected not only to examine the hospitality sector however they also need to analyze other service industries namely logistics, banking, airlines, hospitals and other companies such as the manufacturing industry and the researchers need to examine other hotel employees located outside Jakarta as respondents.

\section{REFERENCES}

[1] Badan Pusat Statistik DKI Jakarta, [Online], Retrieved from: https://jakarta.bps.go.id/

[2] Cari Hotel Murag dan Promo [Onine]. Retrieved from: https://www.pegipegi.com

[3] S.K. Singh, T.F. Burgess, J. Heap and N. Al Mehrzi, "Competing through employee engagement: a proposed framework," Int J Product Perform Manag, Published online, 2016.

[4] S. Popli and I.A. Rizvi, "Leadership style and service orientation: the catalytic role of employee engagement," Journal of Service Theory and Practice, vol. 27, no. 1, pp. 292-310, 2007.

[5] A. Benyoussef Zghidi and I. Zaiem, "Service orientation as a strategic marketing tool: the moderating effect of business sector," Competitiveness Review, vol. 27, no. 1, pp. 40-61, 2017.

[6] R. Eisenberger and R. Huntington, Perceived organizational support and employee diligence, commitment, and innovation, 2001.

[7] J.N. Kurtessis, R. Eisenberger, M.T. Ford, L.VC. Buffardi, K.A. Stewar and C.S. Adis, "Perceived Organizational Support: A Meta-Analytic Evaluation of Organizational Support Theory," Journal of Management, vol. XX, no. X, pp. 1-31, 2015.

[8] R.S. Lytle and J.E. Timmerman, "Service orientation and performance An organizational perspective," Journal of Services Marketing, vol. 20, no. 2, pp. 136-14, 2006

[9] D.E. Bowen and B. Schneider, "A Service Climate Synthesis and Future Research Agenda," Journal of Service Research, vol. 17, no. 1, pp. 5-22, 2014

[10] P. Neves and R. Eisenberger, "Perceived organizational support and risk taking," Journal of Managerial Psychology, vol. 29, no. 2, pp. 187-205, 2014

[11] S.K. Mishra, "Linking perceived organizational support to emotiona labor," Personnel Review, vol. 43, no. 6, pp. 845-860, 2014.

[12] I. Ahmed, M.M. Nawaz, G. Ali and T. Islam, "Perceived organizationa support and its outcomes," Management Research Review, 2015.

[13] S.C. Chang and M.S. Lee, "A study on relationship among leadership, organizational culture, the operation of learning organization and employees' job satisfaction," Learning Organization, vol. 14, no. 2, pp. $155-185,2007$.

[14] S. Swathi, "Effecting Employee Engagement Factors," Internationa Journal of Scientific and Research Publications, vol. 3, no. 8, pp. 2250 3153,2013

[15] C. Maden, Article information, 2015

[16] K.R. Johnson, S. Park and K.R. Bartlett, "Perceptions of custome service orientation, training, and employee engagement in Jamaica's hospitality sector," European Journal of Training and Development, vol. 42m pp. (3-4), no. 191-209, 2018

[17] A.M. Saks and J. Rotman, "Antecedents and consequences of employee engagement," Journal of Managerial Psychology, vol. 21, no. 7, pp. 600-619, 2006

[18] O. Nazir and J.U. Islam, "Enhancing organizational commitment and employee performance through employee engagement," South Asian Journal of Business Studies, 6(1), 98-114, 2017.

[19] M. Karanika-Murray, N. Duncan, H.M. Pontes and M.D. Griffiths, "Organizational identification, work engagement, and job satisfaction," Journal of Managerial Psychology, vol. 30, no. 8, pp. 1019-1033, 2015.

[20] S. Malhotra, "A Study of Relationship Between Job Satisfaction and Employee," vol. 2, pp. 1-13, 2016. 